\title{
EFFECT OF PRESSING TEMPERATURES ON BONDING PROPERTIES OF SUCROSE-CITRIC ACID FOR NIPA PALM FRONDS PARTICLEBOARD
}

\author{
Mahdi Santoso \\ Palangka Raya University \\ INDONESIA \\ Ragil Widyorini, Tibertius Agus Prayitno, Joko Sulistyo \\ Universitas Gadjah Mada \\ INDONESIA \\ Noor Hamidah \\ Palangka Raya University \\ INDONESIA \\ (Received November 20I9)
}

\begin{abstract}
The objective of this study was to investigate the properties of nipa front particleboard bonded using the combination of sucrose and citric acid, and the effect of different pressing temperature. The results showed that the adding citric acid to sucrose and increasing pressing temperature increased the physical and mechanical properties of the nipa fronds particleboards. FTIR analysis results indicated that the peak intensity of $\mathrm{C}=\mathrm{O}$ ester group and $\mathrm{C}-\mathrm{O}-\mathrm{C}$ hemiacetal group increased and the hydroxyl $\mathrm{OH}$ groups decreased with increasing pressing temperature and addition of citric acid, which indicated that crosslinking between sucrose and citric acid occurred. TG-DTA analysis confirm that increasing pressing temperature and addition of citric acid to sucrose increasing thermal stability of nipa fronds particleboards, which is suspected caused by the polycondensation reaction between sucrose and citric acid.
\end{abstract}

KEYWORDS: Sucrose, citric-acid, particleboards, nipa frond.

\section{INTRODUCTION}

Synthetic wood adhesives based on formaldehyde has been used for a long time and has been known have excellent performance, good working properties and are economically satisfactory. 
However, these adhesives are carcinogenic to humans, can cause irritation of the eyes and throat, respiratory disorders, and have a nature as non-renewable and non-biodegradable materials (Roffael 1993). With steadily increasing of environmental and health awareness, natural binders from renewable and biodegradable resources regained attraction as alternative bonding agents. Natural binder using bio-resources have been conducted to development eco-friendly bio-composites such a saccharide based such a starch (Hosseinpourpia and Adamopoulos 2018, Tondi 2012) and cellulose (Wang et al. 2018), protein based such a soy protein (Wu et al. 2018) and white gluten (Nordqvist et al. 2012), aromatic based such a lignin (Bouajila et al. 2005) and tannin (Zhang et al. 2019, Zhao and Umemura 2014), oil based such a castor oil and canola oil (Li et al. 2015), and others such a polycarboxylic acids (Umemura et al. 2012) and natural rubber (Thuraisingam et al. 2016). Sucrose and citric acid has potential to be developed as a natural binder for replacement synthetic adhesives (Umemura et al. 2012, 2013, Lamaming et al. 2013, Widyorini et al. 2016a, Santoso et al. 2016, 2017). The utilization of sucrose as natural binder on particleboards has been done among on softwood (Umemura et al. 2013, 2014, Zhao and Umemura 2014), hardwood (Widyorini et al. 2016a), and non-wood (Lamaming et al. 2013, Liao et al. 2016, Akgül et al. 2017, Santoso et al. 2017, 2019).

One of sucrose weakness as a natural binder was has the dimensional stability very low (Zhao dan Umemura 2014, Widyorini et al. 2016a). Widyorini et al. (2016a) reported that thickness swelling of teak wood sucrose bonded particleboards reaches $62 \%$, and water absorption about $135 \%$, same with the binderless particleboards about $66 \%$ and $161 \%$ respectively. Zhao and Umemura (2014), mentioned that on softwood particleboard sucrose bonded has very low dimensional stability properties with thickness swelling reaches more than $80 \%$. The low water resistance of sucrose as a natural binder was due to the nature of the sucrose. When sucrose exposed at high temperatures, is converted into caramel which is a high solubility and high hydroxyl group material. Adding citric acid to sucrose can resolve that problem. The mechanism involved is the formation of crosslinks between carboxyl $(\mathrm{COOH})$ groups of citric acid with hydroxyl $(\mathrm{OH})$ groups in the sucrose and or lignocellulosic materials (Umemura et al. 2012). The hydrophilic of hydroxyl group replaced with hydrophobic of ester groups, and the particleboards becomes more resistant to moisture interference from the environment (Reddy and Yang 2010, Umemura et al. 2013, Widyorini et al. 2016a).

Pressing temperature was an important parameter of the reaction between carboxyl groups and hydroxyl groups to form ester groups (McSweeny et al. 2006). Sucrose and citric acid has different melting temperatures, and melting temperatures suggested influence to the crosslinks reaction between carboxyl groups from citric acid and hydroxyl groups (Umemura et al. 2012, Widyorini et al. 2016a). Umemura et al. $(2012,2015)$ reported that citric acid bonded mouldings from acacia mangium and citric acid bonded particleboards from softwood, increasing pressing temperature from $160^{\circ} \mathrm{C}$ to $180^{\circ} \mathrm{C}$ increased the mechanical properties of composites up to twice. The pressing temperature at $180^{\circ} \mathrm{C}$ is reach the melting point of citric acid and likely to be a critical temperature for bending properties. Several studies have concluded that the ideal pressing temperature for citric acid based binder is between $180-200^{\circ} \mathrm{C}$ (Umemura et al. 2012 , 2015). While on sucrose it is reported that an increase in temperature up to $200^{\circ} \mathrm{C}$ will produce particleboard with the best bonding properties (Umemura et al. 2013, 2015, Zhao and Umemura 2014, Widyorini et al. 2016a). Differences of melting point between citric acid and sucrose (citric acid about $176^{\circ} \mathrm{C}$ and sucrose about $183^{\circ} \mathrm{C}$ ) are thought to play a important role in the optimum temperature of particleboards process.

Research on natural binder have been initiated in an attempt to increase the quality of the non wood lignocellulose particleboards. Therefore, this paper was designed to investigate the nipa front particleboard properties (as non wood lignocellulose material) bonded using sucrose and 
citric acid (as natural binder) and their combination with various compositions. Considering that the melting temperatures of sucrose and citric acid are different, the effect of pressing temperature was also studied in this research.

\section{MATERIAL AND METHODS}

\section{Board materials}

Nipa fronds were collected from the Jatimalang Beach Purworejo Middle Java Province. Particles were passed through aperture sizes of 10 mesh with bulk density of $0.135 \mathrm{~g}^{\mathrm{cm}} \mathrm{cm}^{-3}$ were used as materials in this research. According to the mesh analysis of particle size, about $86.26 \%$ of the particles used between 10-40 mesh, 7.15\% between 40-60 mesh, 4.58\% between $60-100$ mesh and $2.01 \%$ passed through 100 mesh. All particles were air-dried to a moisture content of around $12 \%$.

\section{Preparation of binder solution}

Sucrose from PT. Multi Kimia Raya Nusantara (Indonesia) and citric acid anhydrous from PT. Budi Starch \& Sweetener (Indonesia), were used without further purification. Sucrose and citric acid were dissolved in distillate water with the solution concentration was adjusted variated to $50 \%$ for sucrose and $60 \%$ for citric acid (wt \%). The mixture ratios of sucrose/citric acid were 100/0, 87.5/12.5, 75/25 and 0/100. The solutions were then used as an adhesive.

\section{Board manufacturing}

The solution was used as a binder and sprayed onto the particles at $20 \%$ resin content based on the weight of air-dried particles. The sprayed particles were then oven-dried for 20 hours at $80^{\circ} \mathrm{C}$ to reduce the moisture content about $4-6 \%$. The particles were hand-formed into a mat using a forming box followed by hot pressing into particleboards with a distance bar of $1 \mathrm{~cm}$ to control board thickness. The boards were pressed at $180^{\circ} \mathrm{C}$ and $200^{\circ} \mathrm{C}$ for 10 min under a specific pressure $3.6 \mathrm{MPa}$. The target density was $0.8 \mathrm{gcm}^{-3}$ with board size of $25 \times 25 \mathrm{~cm}$. Prior to the evaluation of the physical and mechanical properties, all boards were conditioned at ambient conditions for approximately one week (7 days). Conditioning is done by storing samples at room temperature to homogenize the moisture content and free up residual stress due to the hot pressing.

\section{Board evaluation}

The particleboards were evaluated according to the Japanese industrial standard for particleboards JIS A 5908 (2003). Tests were carried out to determine density, moisture content, thickness swelling, water absorption, surface roughness, internal bonding strength, modulus of rupture and modulus of elasticity. Static three-point bending tests were conducted on a $20 \times$ $5 \times 1 \mathrm{~cm}$ specimen. The effective span and loading speed were $15 \mathrm{~cm}$ and $1 \mathrm{~cm} \cdot \mathrm{min}^{-1}$, respectively. The density, moisture content, thickness swelling, water absorption and internal bond strength test was performed on a $5 \times 5 \times 1 \mathrm{~cm}$ specimen cut from each board. The thickness swelling and water absorption tests after water immersion for $24 \mathrm{~h}$ at room temperature. The surface roughness was measured using portable surface roughness tester (SRG-4000), where average roughness ( $\mathrm{Ra}$ ) was used to evaluate roughness characteristics of the particleboards and eight measurements were randomly taken from both surfaces of the $20 \times 5 \times 1 \mathrm{~cm}$ specimen. Infra-red spectra (FTIR) analysis with Shimadzu IR Prestige-21 tool were obtained using the $\mathrm{KBr}$ disk method and 
recorded by means of an average of 10 scans at a resolution of $16 \mathrm{~cm}^{-1}$ on a 100 -mesh powder that had previously been immersed in boiling water for 2 hours and cold water 1 hour and dried to remove the excess and unreacted citric acid. The thermal analysis (TG-DTA) with Shimadzu DTG-60 tool on a pass 100 mesh powder, nitrogen gas atmosphere with an average flow of 30 $\mathrm{ml} \cdot \mathrm{min}^{-1}$ and the starting temperature of the test was $30^{\circ} \mathrm{C}$ with a temperature rise of $10^{\circ} \mathrm{C} \cdot \mathrm{min}^{-1}$ and the maximum test at $300^{\circ} \mathrm{C}$. Analysis of variants (ANOVA) with two factors conduct on physical and mechanical properties for statistical analysis. Each experiment was performed in triplicate, and the average value and standard deviation were calculated for data displayed.

\section{RESULTS AND DISCUSSION}

\section{Physical properties}

The board densities of particleboards ranged from $0.81 \mathrm{~g} \cdot \mathrm{cm}^{-3}$ to $0.92 \mathrm{~g} \cdot \mathrm{cm}^{-3}$ irrespective of the condition of manufacture, and their moisture contents were in the range of $4.41 \%$ to $11.70 \%$ which means it meets the JIS 5908 (2003) standard which requires 5-13\%. All of the particleboards could be manufactured without any delamination. Color of the particleboards became darker with increasing pressing temperature, indicating a high degree of hydrolysis or other modification of chemical components during treatment as shown in the research of Widyorini et al. (2016a). There was no remarkable difference in color between the different kind of composition ratio of sucrose/citric acid. Increased pressing temperatures also decrease moisture content of particleboards, indicating high water vapor release during pressing process. Difference in moisture content also found on different composition ratio of sucrose/citric acid, adding citric acid on sucrose look like make the moisture content of particleboards decrease.

Tab. 1: Physical properties of nipa fronds particleboards on various pressing temperatures and ratio of sucrose/citric acid.

\begin{tabular}{|l|c|c|c|c|c|}
\hline $\begin{array}{l}\text { Ratio of sucrose/ } \\
\text { citric acid-pressing } \\
\text { temperatures }\end{array}$ & $\begin{array}{c}\text { Density } \\
\left(\mathbf{g} \cdot \mathbf{c m}^{-3}\right)\end{array}$ & $\begin{array}{c}\text { Moisture } \\
\text { content } \\
\mathbf{( \% )}\end{array}$ & $\begin{array}{c}\text { Thickness } \\
\text { swelling } \\
\mathbf{( \% )}\end{array}$ & $\begin{array}{c}\text { Water } \\
\text { absorption } \\
(\mathbf{\%})\end{array}$ & $\begin{array}{c}\text { Surface } \\
\text { roughness } \\
(\boldsymbol{\mu m})\end{array}$ \\
\hline $100 / 0-180^{\circ} \mathrm{C}$ & $0.87(0.02) \mathrm{bc}$ & $9.02(0.84) \mathrm{cd}$ & $6.14(1.52) \mathrm{b}$ & $28.36(1.23) \mathrm{b}$ & $7.23(0.21) \mathrm{d}$ \\
\hline $87.5 / 12.5-180^{\circ} \mathrm{C}$ & $0.89(0.03) \mathrm{cd}$ & $10.21(0.41) \mathrm{d}$ & $2.45(0.50) \mathrm{a}$ & $23.55(1.33) \mathrm{b}$ & $5.13(0.25) \mathrm{bc}$ \\
\hline $75 / 25-180^{\circ} \mathrm{C}$ & $0.92(0.03) \mathrm{d}$ & $11.70(1.71) \mathrm{e}$ & $1.83(0.04) \mathrm{a}$ & $23.59(0.98) \mathrm{b}$ & $5.77(0.22) \mathrm{c}$ \\
\hline $0 / 100-180^{\circ} \mathrm{C}$ & $0.84(0.01) \mathrm{ab}$ & $6.71(0.20) \mathrm{b}$ & $4.58(0.68) \mathrm{a}$ & $38.83(0.24) \mathrm{c}$ & $4.90(0.44) \mathrm{b}$ \\
\hline $100 / 0-200^{\circ} \mathrm{C}$ & $0.84(0.01) \mathrm{ab}$ & $6.99(0.84) \mathrm{b}$ & $59.52(14.25) \mathrm{c}$ & $49.22(7.73) \mathrm{d}$ & $9.14(0.11) \mathrm{e}$ \\
\hline $87.5 / 12.5-200^{\circ} \mathrm{C}$ & $0.84(0.01) \mathrm{ab}$ & $5.23(0.27) \mathrm{a}$ & $1.43(0.30 \mathrm{a}$ & $23.03(1.54) \mathrm{b}$ & $5.33(0.87) \mathrm{bc}$ \\
\hline $75 / 25-200^{\circ} \mathrm{C}$ & $0.89(0.03) \mathrm{cd}$ & $7.75(0.48) \mathrm{bc}$ & $0.38(0.14) \mathrm{a}$ & $16.97(0.75) \mathrm{c}$ & $4.20(0.19) \mathrm{a}$ \\
\hline $0 / 100-200^{\circ} \mathrm{C}$ & $0.81(0.02) \mathrm{ab}$ & $4.41(0.49) \mathrm{a}$ & $2.82(0.39) \mathrm{a}$ & $34.20(1.32) \mathrm{c}$ & $4.19(0.18) \mathrm{a}$ \\
\hline Ref. value JIS 5908:2003 & $0.40-0.90$ & $5-13$ & Max. $12 \%$ & Not required & Not required \\
\hline
\end{tabular}

Values in parentheses are standard deviation. Mean values followed by different letters at the same column indicate that are significantly different $(\mathrm{p}<0.05)$.

Based on Tab. 1, it can be seen that dimensional stability (thickness swelling and water absorption) in this study strongly influenced by the pressing temperatures and ratio of sucrose/ citric acid. The dimensional stability of sucrose bonded particleboards at pressing temperature $180^{\circ} \mathrm{C}$ and $200^{\circ} \mathrm{C}$ was similar with another research before by another researcher. Widyorini et al. (2016a) found on teak wood particleboards bonded with sucrose at pressing temperature 
$180^{\circ} \mathrm{C}$ that have a thickness swelling and water absorption about $62 \%$ and $135 \%$ respectively. Umemura et al. (2013) reported that the value of thickness swelling of softwood particleboards bonded with sucrose ( $20 \%$ resin content, $200^{\circ} \mathrm{C}$ pressing temperature, and 10 min pressing time) reached more than $100 \%$. Zhao and Umemura (2014) also reported that softwood particleboards with $20 \%$ sucrose, $200^{\circ} \mathrm{C}$ pressing temperatures and 10 min pressing time resulted in thickness swelling more than $80 \%$. This phenomenon could be due to the nature of sucrose, that was converted into a high solubility material when heated at temperature about $200^{\circ} \mathrm{C}$, causing the particleboards have low dimensional stability (Umemura et al. 2013, Widyorini et al. 2016a).

The surface roughness ranged from 4.19-9.14 $\mu \mathrm{m}$ (Tab. 1). All particleboards that are bonded with sucrose/citric acid ratio 100/0 have surface roughness that does not meet the criteria (3.67-5.46 $\mu \mathrm{m}$ ) submitted by Hiziroglu and Suzuki (2007). The addition of citric acid to sucrose has a significant effect on the particle surface roughness level. According to Hiziroglu and Suzuki (2007) one of the factors affecting surface roughness is the densification of the surface layer of the particleboards. High surface densification levels will result in smooth surface roughness. Densification of surface of the particleboards is strongly influenced by contact between the particles. According to Widyorini et al. (2016b) and Santoso et al (2019), the addition of citric acid as a binder will result in better contact between the particles and has better adhesive properties, and will result in smoother of particleboards surfaces.

\section{Mechanical properties}

Increased pressing temperatures and addition of citric acid to sucrose effect to increasing internal bonding (Fig. 1), modulus of rupture (Fig. 2) and modulus of elasticity (Fig 3.) of the nipa fronds particleboards. This result is similar to some previous studies which concluded that particleboards bonded with combination of sucrose/citric acid had optimal pressing temperature at $200^{\circ} \mathrm{C}$ (Umemura et al. 2015, Widyorini et al. 2016a).

Umemura et al. (2012) reported that the melting temperature of the binder is a critical point of bonding between the binder and raw material particles. As known the melting point of sucrose about $187.5^{\circ} \mathrm{C}$, and the formation of a strong bond only to occur at that temperature or more. Tondi et al. (2012), Zhao and Umemura (2014) reported that at temperature about $200^{\circ} \mathrm{C}$, sucrose will be isomerized and degraded into a reactive puranic compound i.e. 5-HMF (hydroxy methyl furfural), hydroxy acetyl furan (HAF), dimethyl dihydroxy furanone (DDF) and monohydroxy dimethyl furanone (MDF). It is further explained, that components are responsible for forming crosslinking on a combination of tannin/sucrose and binder hardening process on a combination of starch/sucrose.

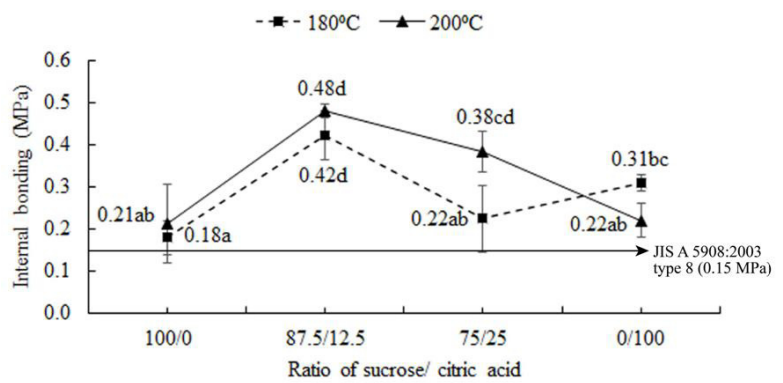

Fig. 1: Internal bonding strength of nip a frond particleboards on various pressing temperatures and ratio of sucrose/citric acid. Error bars indicate standard deviation. Mean values followed by different letters indicate that are significantly different $(p<0.05)$. 


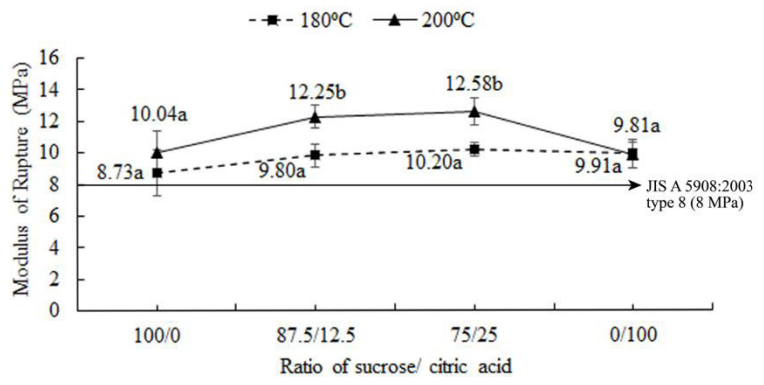

Fig. 2: Modulus of rupture (MOR) of nipa frond particleboards on various pressing temperatures and ratio of sucrose/citric acid. Error bars indicate standard deviation. Mean values followed by different letters indicate that are significantly different $(p<0.05)$.

In the binder ratio sucrose/citric acid 0/100, increase of pressing temperature has an impact on decrease of the internal bonding strength, while on the modulus of rupture and modulus of elasticity is only slightly decreased. According to Umemura et al. (2015), internal bonding strength is strongly influenced by the degree of adhesiveness in the inner layers of the particleboards, while on the modulus of rupture and modulus of elasticity is influenced by the degree of adhesiveness of the surface layer of the particleboards. It is further explained, the high pressing temperatures will produce steam pressures from water vapor and volatile compounds, and affect to the degree of adhesiveness on the inside of the particleboards.

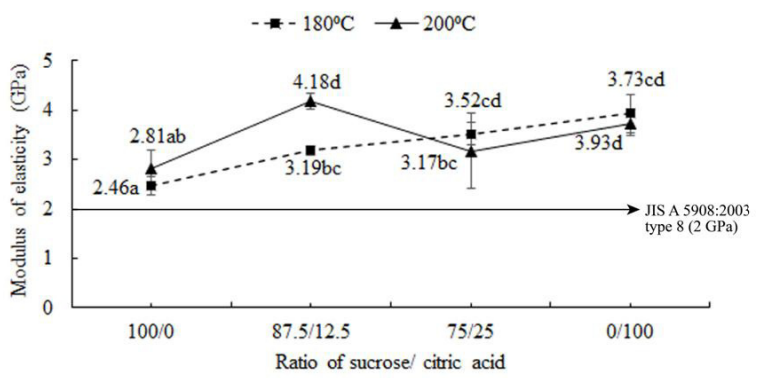

Fig. 3: Modulus of elasticity (MOE) of nipa frond particleboards on various pressing temperatures and ratio of sucrose/citric acid. Error bars indicate standard deviation. Mean values followed by different letters indicate that are significantly different $(p<0.05)$.

\section{Chemical properties}

Infra-red spectrum analyzes (Fig. 4) show that the absorption area around $3400 \mathrm{~cm}^{-1}$ wavelengths (hydroxyl group) is a little decrease in intensity in line with the increase of pressing temperatures and addition of citric acid to sucrose. According to Liao et al. (2016), decrease in absorption intensity at wavelengths around $3400 \mathrm{~cm}^{-1}$ signifies the reduction of free hydroxyl groups that reacted with citric acid and sucrose to form ester and hydrogen bonds on the particleboards. 

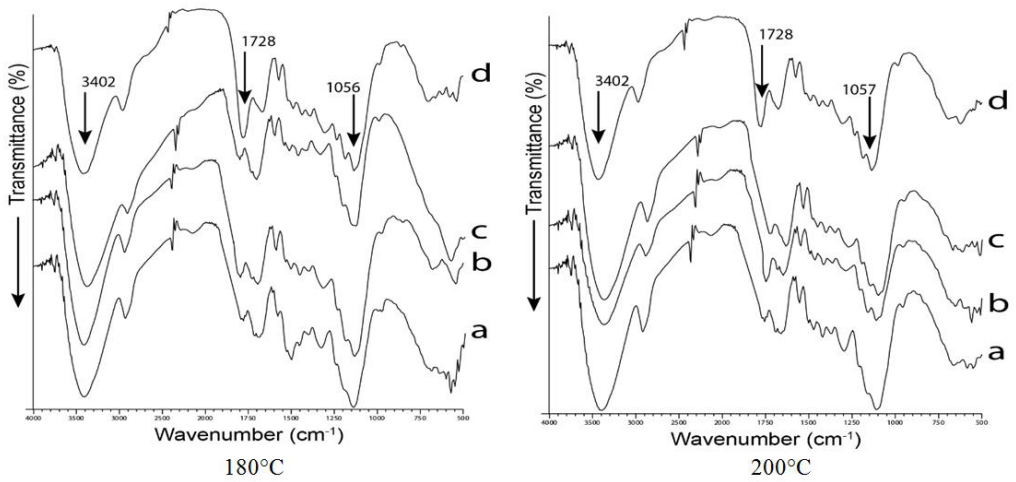

Fig. 4: FTIR analysis pressing temperatures $180^{\circ} \mathrm{C}$ and $200^{\circ} \mathrm{C}$, and ratio of sucrose/citric acid $100 / 0$ (a), $87.5 / 12.5(b), 75 / 25$ (c), and $0 / 100(d)$.

In the absorption area around $1057 \mathrm{~cm}^{-1}$ wavelengths, there was also detected change of intensity with the addition of citric acid to sucrose with the highest intensity at ratio sucrose/citric acid 87.5/12.5. There is no detected effect of increasing pressing temperature on this wavelengths. According to Liao et al. (2016), this could be the vibration of hemiacetal C-O-C strain, the addition of citric acid to sucrose leads to increased $\mathrm{C}-\mathrm{O}-\mathrm{C}$ uptake indicating an esterification between citric acid and cellulose, hemicellulose and sucrose to the reinforcement of particleboards bonding properties.

\section{Thermal properties}

On the ratio of sucrose/citric acid 0/100 bonded particleboards, increasing the pressing temperature influence to the thermal properties of particleboard. The particleboard with high pressing temperature has a high thermal stability because the substances of nipa fronds particles (raw material) or derived from citric acid decomposition during hot press, while on the lower pressing temperature $\left(180^{\circ} \mathrm{C}\right)$ that substances still not decomposition yet. Based on DTA curve (Fig. 5), a broad endotherm was observed at around $125^{\circ} \mathrm{C}$, this point could be due to the weakening of the hydrogen bonds between carbohydrates and/or particleboards, and a endotherm at around $210^{\circ} \mathrm{C}$ would have been due to the decomposition of substances derived from citric acid (Umemura et al. 2012).

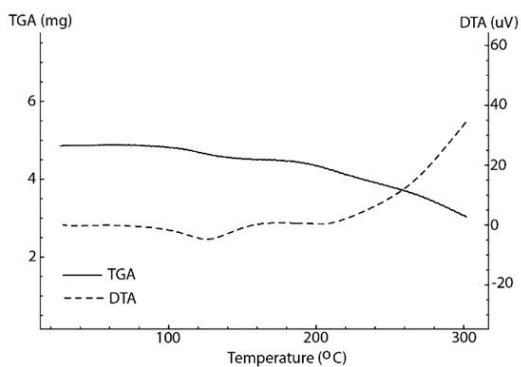

$180^{\circ} \mathrm{C}$

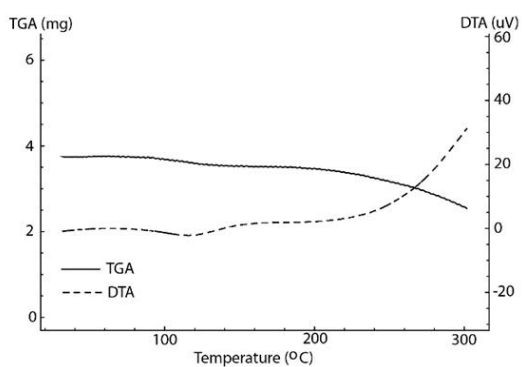

$200^{\circ} \mathrm{C}$

Fig. 5: TG-DTA analysis on nipa frond particleboards at ratio sucrose/citric acid $0 / 100$ and various pressing temperatures. 

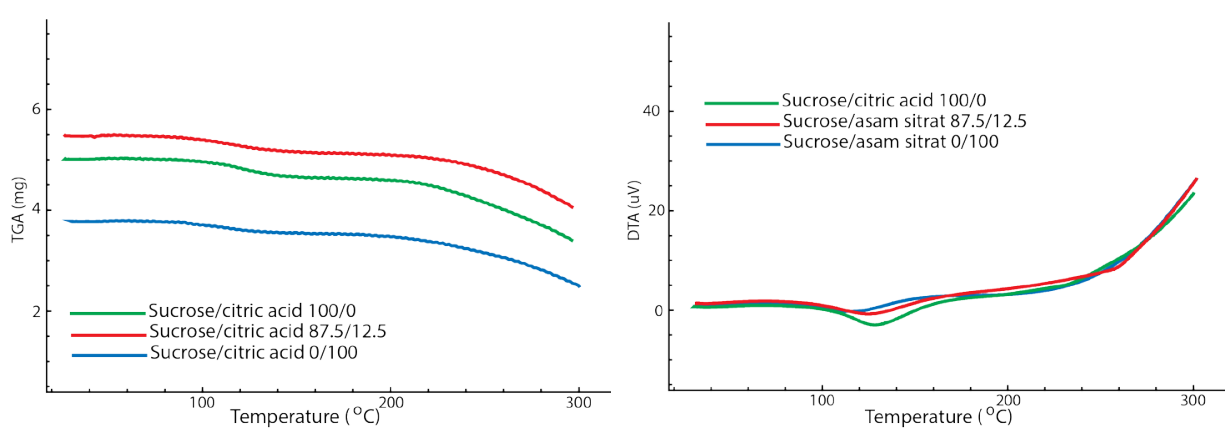

Fig. 6: TG-DTA analysis on nifa frond particleboards at pressing temperature $200^{\circ} \mathrm{C}$ and various ratio sucrose/citric acid.

Based on the thermogravimetric analysis (TG-DTA) (Fig. 6), it is known that on the sucrose/citric acid 0/100 bonded particleboards, thermal degradation detected at $193^{\circ} \mathrm{C}-249^{\circ} \mathrm{C}$ which is could be a derivate of citric acid that has not been degraded on particleboards pressing process. Umemura et al. $(2012,2013)$ and Castro-Cabado et al. (2016) reported that citric acid has a thermal degradation point at $150-250^{\circ} \mathrm{C}$ (melting point at $153^{\circ} \mathrm{C}$ and dehydrated to forming asonic acid at $175^{\circ} \mathrm{C}$ ). It is further explained, the thermal degradation around $200^{\circ} \mathrm{C}$ is a decomposition of the citric acid to produce water and carbon dioxide.

On the sucrose/citric acid 100/0 bonded particleboards found different results, the thermal degradation occurred at a temperature of $203-259^{\circ} \mathrm{C}$, which is could be come from depolymerization of polysaccharide macromolecule (caramelization of sucrose) (Zhao and Umemura 2014, Castro-Cabado 2016). The combination of sucrose/citric acid at ratio 87.5/12.5 has a higher thermal degradation at $248^{\circ} \mathrm{C}-289^{\circ} \mathrm{C}$, which is could be related to the formation of crosslinks between sucrose and citric acid to forms ester bonds during the hot press. According to Castro-Cabado et al. (2016), the polycondensation reaction between citric acid and polysaccharide (maltodextrin) will produce a component with a degradation point at a temperature around $284^{\circ} \mathrm{C}$.

\section{CONCLUSIONS}

Increased the pressing temperatures from $180^{\circ} \mathrm{C}$ to $200^{\circ} \mathrm{C}$ and added citric acid to sucrose can significantly improve the particleboards bonding properties. The melting point of binder is thought to play an important role in the formation of the bonding properties. The combination of sucrose/citric acid at ratio $87.5 / 12.5$ and pressing temperature $200^{\circ} \mathrm{C}$ producing particleboards with excellent quality by meeting JIS A 5908 (2013). The properties of particleboards on optimal condition was density $0.84 \mathrm{~g} \mathrm{~cm}^{-3}$, moisture content $5.23 \%$, thickness swelling $1.43 \%$, water absorption $23.03 \%$, internal bonding $0.48 \mathrm{MPa}$, modulus of rupture $12.25 \mathrm{MPa}$, modulus of elasticity $4.18 \mathrm{GPa}$ and surface roughness $5.33 \mu \mathrm{m}$. FTIR analysis showed that the $\mathrm{C}=\mathrm{O}$ ester and hemiasetal $\mathrm{C}-\mathrm{O}-\mathrm{C}$ bonds increased with adding citric acid and increasing pressing temperature, while the hydroxyl $\mathrm{OH}$ groups decreased. TG-DTA analysis showed that the increasing the pressing temperature and adding citric acid to sucrose increasing the thermal stability of the nipa fronds particleboards. 


\section{REFERENCES}

1. Bouajila, J., Limare, A., Joly, C., Dole, P., 2005: Lignin plasticization to improve binderless fiberboard mechanical properties. Polymer Engineering and Science 45(6): 809-816.

2. Castro-Cabado, M., Casado, A.L., Román, J.S., 2016: Bio-based thermosets: Effect of the structure of polycarboxylic acids on the thermal crosslinking of maltodextrins. European Polymer Journal 78: 91-105.

3. Hiziroglu, S., Suzuki, S., 2007: Evaluation of surface roughness of commercially manufactured particleboard and medium density fiberboard in Japan. Journal of Material Processing Technology 184(1-3): 436-440.

4. Hosseinpourpia, R., Adamopoulos, S., 2019: Properties of medium-density fibreboards bonded with dextrin-based wood adhesive. Wood Research 64(2): 185-194.

5. JIS A 5908, 2003: Particleboard.

6. Lamaming, J., Sulaiman. O., Sugimoto, T., Hashim, R., Said, N., Sato, M., 2013: Influence of chemical components of oil palm on properties of binderless particleboard. BioResources 8(3): 3358-3371.

7. Li, N., Qi, G., Sun, X.S. dan Wang, D., 2015: Canola protein and oil-based wood adhesives. In: Bio-based wood adhesives: preparation, characterization, and testing. Chapter 4, (ed Z. He). Pp 111-139, CRC Press: Boca Raton, FL, USA.

8. Liao, R., Jianying X., Umemura, K., 2016: Low density sugarcane bagasse particleboard bonded with citric acid and sucrose: effect of board density and additive content. BioResources 11(1): 2174-2185.

9. McSweeny, J.D., Rowel, R.M., Min, S.H., 2006: Effect of citric acid modification of aspen wood on sorption of copper ion. Journal of Natural Fiber 3(1): 43-58.

10. Nordqvist, P., Thedjil, D., Khosravi, S., Lawther, M., Malmstrom, E., Khabbaz, F., 2012: Wheat gluten fractions as wood adhesives- glutenins versus gliadins. Journal of Applied Polymer Science 123: 1530-1538.

11. Reddy, N., Yang, Y., 2010: Citric acid cross-linking of starch films. Food Chemical 118(3): 702-711.

12. Roffael, E., 1993: Formaldehyde release from particleboard and other wood based panels. Malayan Forest Records No 37. Forest Research Institute Malaysia (FRIM), Kepong, Kuala Lumpur, $281 \mathrm{pp}$.

13. Santoso, M., Widyorini, R., Prayitno, T.A., Sulistyo, J., 2016: Quality of the nipa frond particleboard bonded with citric acid and sucrose. Journal of Forest Science 10(2): 129-136.

14. Santoso, M., Widyorini, R., Prayitno, T.A., Sulistyo, J., 2017: Bonding performance of maltodextrin and citric acid for particleboard made from nipa fronds. Journal of the Korean Wood Science and Technology 45(4): 432-443.

15. Santoso, M., Widyorini, R., Prayitno, T.A., Sulistyo, J., 2019. The effects of extractives substances for bonding performance of three natural binder on nipa fronds particleboard: in The UGM Annual scientific conference life sciences 2016. KnE Life Sciences, Pp 227-238.

16. Tondi, G., Wieland, S., Wimmer, T., Schnabel, T., Petutschnigg, A., 2012: Starch-sugar synergy in wood adhesion science: basic studies and particleboard production. European Journal of Wood and Wood Products 70: 271-278.

17. Thuraisingam, J., Gupta A., Subramaniam, M., 2016: Natural rubber latex (NRL) and rice starch as an alternative binder in wood composite industry. Australian Journal of Basic and Applied Sciences 10(17): 101-106.

18. Umemura, K., Ueda T, Munawar S.S., Kawai S., 2012: Application of citric acid as natural adhesive for wood. Journal of Applied Polymer Science 123(4): 1991-1996. 
19. Umemura, K. Sugihara, O., Kawai, S., 2013: Investigation of a new natural adhesive composed of citric acid and sucrose for particleboard. Journal of Wood Science 59(3): 203-208.

20. Umemura, K., Sugihara, O., Kawai, S., 2015: Investigation of a new natural adhesive composed of citric acid and sucrose for particleboard II: effect of board density and pressing temperature. Journal of Wood Science 61(1): 40-44.

21. Wang, L., Ge, S., Li, D., Yang, W., Peng, W., 2018: Characteristics of nontoxic bamboo bioboard by melamine and cellulose adhesive. Wood Research 63 (2): 287-294.

22. Widyorini, R., Nugraha, P.A., Rahman, M.Z.A., Prayitno, T.A., 2016a: Bonding ability of a new adhesive composed of citric acid-sucrose for particleboard. BioResources 11(2): 4526-4535.

23. Widyorini, R., Umemura, K., Isnan, R., Putra, D.R., Awaluddin, A., Prayitno, T.A., 2016b: Manufacture and properties of citric acid-bonded particleboard made from bamboo materials. European Journal of Wood and Wood Products 74: 57-65.

24. Wu, Z., Xi, X., Yu, L., Su, L., 2018: An eco-friendly urea-formaldehyde resin: preparation structure and properties. Wood Research 63(1): 45-56.

25. Zhao, Z., Umemura, K., 2014: Investigation of a new natural particleboard adhesive composed of tannin and sucrose. Journal of Wood Science 60(4): 269-277.

26. Akgül, M., Uner, B., Çamlibel, O., Ayata, Ü., 2017: Manufacture of medium density fiberboard (MDF) panels from agribased lignocellulosic biomass. Wood Research 62(4): 615-624.

27. Zhang, J., Xiong, L., Zhou, X., Du, G., 2019: Development of mimosa tannin-based adhesive cross-linked by furfuryl alcohol-formaldehyde and epoxy resins. Wood Research 64(5): 847-858.

\author{
Mahdi Santoso* \\ Palangka Raya University \\ Faculty of Agriculture Department of Forestry \\ Yos Sudarso Street, 73iila \\ Palangka Raya \\ INDONESIA \\ *Corresponding author: mahdisantoso@gmail.com \\ Ragil Widyorini, Tibertius Agus Prayitno, Joko Sulistyo \\ Universitas Gadjah Mada \\ Faculty of Forestry Department of Forest Product Technology \\ 1 Agro Street, 5528I \\ YOGYAKARTA \\ INDONESIA \\ Noor Hamidah \\ Palangka Raya University \\ Faculty of Engineering \\ Department of Architecture \\ Yos Sudarso Street, 73i ila \\ Palangka Raya \\ INDONESIA
}

